\title{
RESIDUAL OSL SIGNALS FROM MODERN GREENLANDIC RIVER SEDIMENTS
}

\author{
HELENA ALEXANDERSON ${ }^{1,2}$ \\ ${ }^{1}$ Department of Physical Geography and Quaternary Geology, \\ Stockholm University, SE-106 91 Stockholm, Sweden \\ ${ }^{2}$ Nordic Laboratory for Luminescence Dating, \\ Aarhus University, Risø National Laboratory, DK-4000 Roskilde, Denmark
}

Received 26 June 2006

Accepted 03 November 2006

\begin{abstract}
Ripple-laminated sandy deposits at shallow water depths in four rivers on Jameson Land, East Greenland were sampled for optically stimulated luminescence (OSL) dating. Silt-sized grains have significantly higher equivalent doses $(\sim 1.1 \mathrm{~Gy})$ than sand grains $(\sim 0.1 \mathrm{~Gy})$. This suggests that coarse grain-size fractions are better bleached and more suitable than fine grains for OSL dating of glaciofluvial/fluvial sediments. A sample from a sidebar deposited during the spring flood yielded 1.0 Gy ( $\sim 500$ years) while a subaerial deposit was completely zeroed. The spring flood deposit is considered to be most similar to deglacial conditions and incomplete bleaching of this amount ( $1 \mathrm{~Gy}$ ) is generally not a significant source of error for sediments of Pleistocene age. Most samples have rather poor luminescence characteristics and are affected by thermal transfer if preheat temperatures at or above $260^{\circ} \mathrm{C}$ are used.
\end{abstract}

Keywords: luminescence dating, OSL, glaciofluvial, fluvial, bleaching, Greenland

\section{BACKGROUND}

\section{Introduction and purpose}

Optically stimulated luminescence (OSL) is one of only few dating methods that can be applied to Late Quaternary glaciogenic deposits and the number of studies using it to decipher glaciation histories has increased rapidly over the last few years (e.g. Richards et al., 2000; Owen et al., 2002; Svendsen et al., 2004; Adrielsson and Alexanderson, 2005; Mäkinen, 2005; Preusser et al., 2005; Thackray et al., 2005; Bøe et al., in press; Kjær et al., 2006). Glacial environments in a number of cases have proved a challenge for OSL dating due to problems related to incomplete bleaching and poor luminescence characteristics (Rhodes and Pownall, 1994; Richards, 2000; Alexanderson and Murray, in press), and a rather pessimistic outlook is offered by some researchers (Mejdahl and Funder, 1994; Gemmell, 1999). However, in other situations the method has provided credible results that are consistent with independent chronological evi-

Corresponding author: H. Alexanderson

e-mail: helena.alexanderson@natgeo.su.se dence (e.g. Hansen et al., 1999; Spencer and Owen, 2004; Preusser et al., 2005). It seems, therefore, that despite some inherent complications it is possible to get good results even from such difficult environments.

To be able to use OSL dating with confidence in glacial environments it is necessary to understand the factors and processes that may contribute to the method's success or failure. This can be achieved by investigating glacial, glaciofluvial and glaciolacustrine sediments of a range of ages in various geographical and geological settings to learn more about how e.g. mineralogy, grain size, mode of transport and choice of analysing techniques affect the results. This paper aims to address the need of knowledge on some of these matters.

The purpose of this study is to examine the degree of bleaching in modern Greenlandic rivers and its dependence on grain size and depositional setting. The study is part of a larger project aiming to date the advances and retreats of the Greenland Ice Sheet and local glaciers on central East Greenland (Fig. 1) during the last two glacial-interglacial cycles with a combination of OSL and cosmogenic exposure dating (Alexanderson and Håkansson, 2006; Håkansson et al., 2006). It has therefore also a second motivation, namely, to increase the quality and 


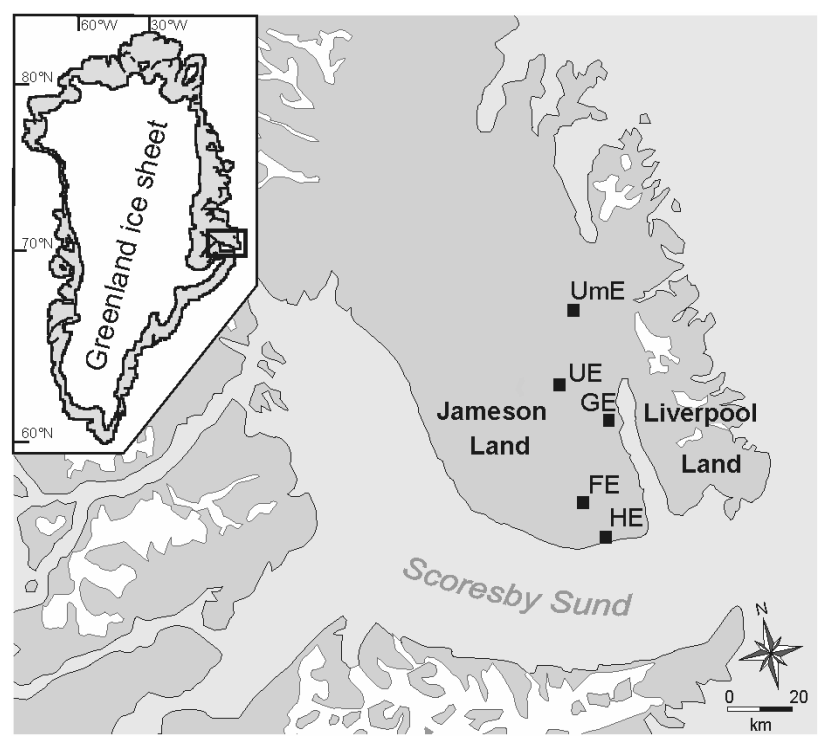

Fig. 1. Location map of Jameson Land and the Scoresbysund area. The black squares mark the sites Umingmakelv River (UmE), Ugleelv Valley (UE), Gåseelv River (GE), Fynselv River (FE) and Hesteelv River (HE). White areas are the Greenland ice sheet and glaciers.

reliability of OSL dates of Pleistocene glaciofluvial sediments in the area by using modern analogues to investigate bleaching conditions and relevant material properties.

\section{OSL in glacial environments}

Complete bleaching, a necessary prerequisite for successful OSL dating of sediments, is especially a concern for glacial and glaciofluvial environments, where subaerial transport distances may be short and water may have a large sediment load. If all grains in a sample were not completely bleached the OSL signal will be a mixture of grains only partly bleached or bleached to various degrees (Duller, 1994), and the resulting age is in most cases inconclusive. If the grains were not bleached at all during deposition (e.g. in a subglacial environment), OSL dating will give the age of the event prior to deposition when the grains were last exposed to sunlight.

Even if bleaching is complete, there are other factors that influence the possibility of measuring luminescence and, in the end, the quality of the OSL age. The factors include the luminescence properties of grains, for example brightness, sensitivity, thermal transfer and recuperation effects (e.g. Rhodes and Pownall, 1994; Rhodes 2000; Hoffower 2002). These characteristics are partly controlled by mineralogy (regional geology) and the mode in which the grains have been transported and deposited. Most of these factors can be accounted for by adapting the analysing protocol to suit a set of samples and the reliability of the results can be tested through various internal controls (dose recovery, preheat plateaus, recycling etc.).

Luminescence methods, including OSL, infrared stimulated luminescence (IRSL) and thermoluminescence (TL), have been applied to modern glaciofluvial sediments in Scandinavia (TL: Gemmell, 1988), on Iceland (TL: Gemmell, 1994), in the Alps (TL: Gemmell, 1997;
IRSL: Gemmell, 1999), in the Himalayas (OSL: Rhodes and Pownall, 1994) and in western Greenland (OSL: Rhodes and Bailey, 1997; Hoffower, 2002). These are locations where glaciers exist today, but are not necessarily where studies of older glaciofluvial deposits are done. Apart from variations in local geology, the geographical location (latitude, altitude) also makes a difference in the amount, intensity and spectrum of sunlight available for bleaching. Insolation has also changed through time, which makes it difficult to determine the similarity between present-day and past bleaching conditions.

These investigations are relatively few but can be complemented by studies of ancient glaciofluvial deposits and, in addition, results from modern fluvial deposits (e.g. Wallinga, 2002; Jain et al., 2004; Alexanderson and Murray, in press) may partly be applicable also to glacial environments. Generally, in fluvial and glaciofluvial environments, quartz is bleached more rapidly than feldspar (Godfrey-Smith et al., 1988; Fuchs et al., 2005) and the residual dose decreases with transport distance, although input from riverbank erosion or from tributaries may change this pattern (Gemmell, 1988; Stokes et al., 2001). Some variation in dose with grain size has also been observed in fluvial and glaciofluvial deposits (Rhodes and Bailey, 1997; Olley et al., 1998; Colls et al., 2001; Truelsen and Wallinga, 2003; Fuchs et al., 2005).

\section{Previous luminescence studies in the area}

Geological studies using luminescence dating have been carried out in the Jameson Land region (Fig. 1) before - within the PONAM program in the 1990s (summarised in Mejdahl and Funder, 1994), by Hansen and others (1999) and by Adrielsson and Alexanderson (2005). These studies have used TL, OSL and IRSL on both feldspar and quartz and include 134 samples covering an age range from $8 \mathrm{ka}$ to $380 \mathrm{ka}$. Mejdahl and Funder (1994) recognize that while shallow marine and fluvial deposits generally produce good results, incomplete bleaching is a significant source of error for ice-proximal sediments and they put most faith in the youngest OSL (feldspar) ages from such depositional settings. Hansen et al. (1999) states that sediments deposited during glacier build-up were better bleached than those deposited during glacier decay (rapid erosion, deposition). A comparison between luminescence and radiocarbon ages from Holocene deltaic sediments suggest that incomplete bleaching may be of the order of a few thousand years (Hansen et al., 1999). Adrielsson and Alexanderson (2005) discuss the degree of bleaching related to different depositional settings (stratigraphical units) but a small number of samples and lack of other chronological data to compare with prevented any quantitative conclusions on its effect.

\section{SAMPLING STRATEGY AND METHODS}

The selection of modern analogue samples was focussed on depositional environments that were most similar, as determined from sedimentological structures and geomorphological setting (see below), to those preserved in older deposits of interest for the study of the glaciation history (Alexanderson and Håkansson, 2006). The sam- 

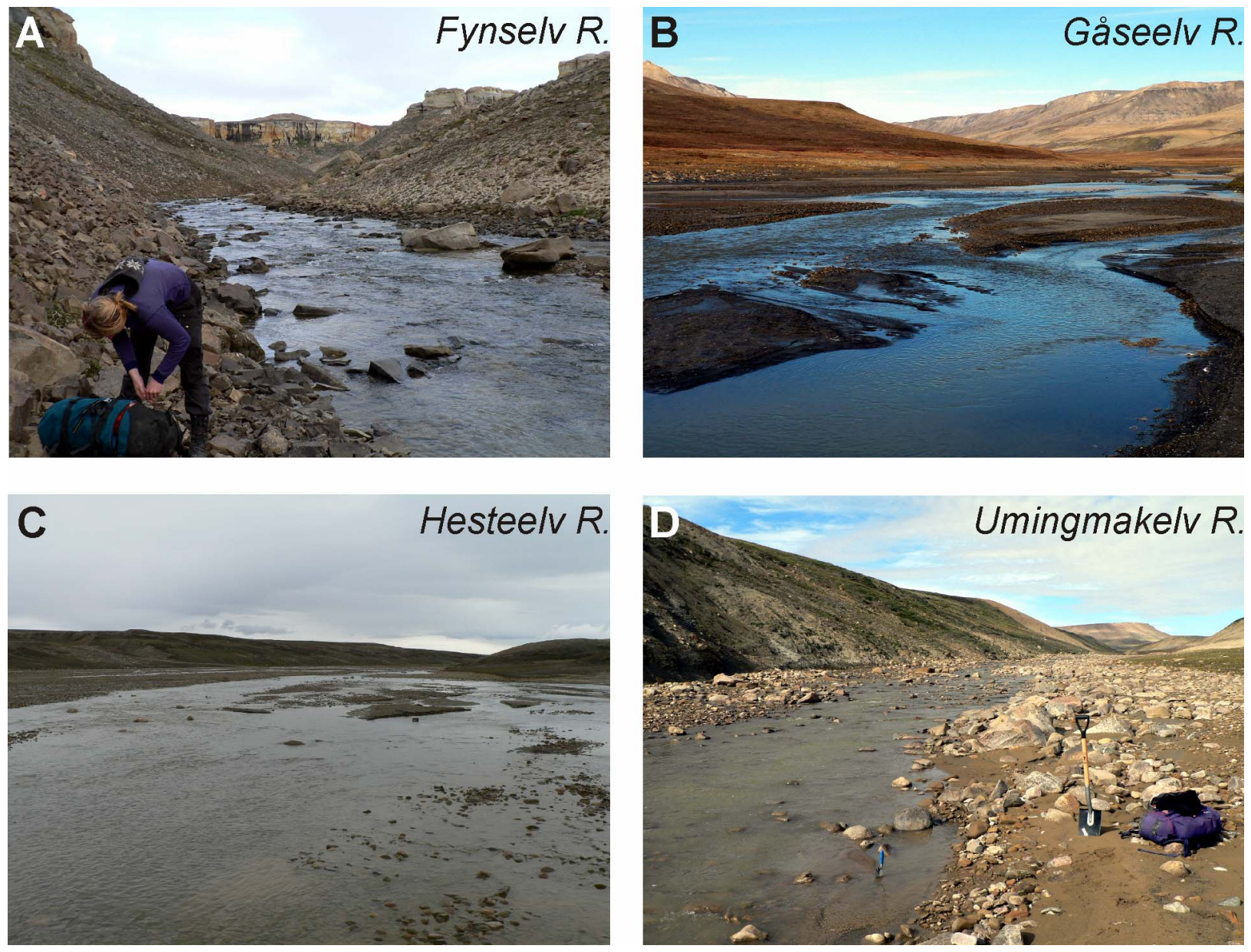

Fig. 2. Photos of the sites. A) The Fynselv River, $\sim 7 m$ wide. B) The Gåseelv River, 10-15 m total width. C) The Hesteelv River, $\sim 50 \mathrm{~m}$ total width. D) The Umingmakelv River, $\sim 8 \mathrm{~m}$ total width.

ples illustrate different depositional conditions related to luminescence; one set of samples of bed sediments in (glacio)fluvial rivers (051332-35) represents the optimal bleaching conditions for glaciofluvial sediments in this area; one sample (051331), most likely deposited during the spring flood, would represent a high discharge event; and one sample (051337) of wind/slope deposits is a reference for subaerial exposure to the natural sunlight spectrum (i.e. no attenuation of light by water and sediment).

The samples, which were taken between 5 and 21 August 2005, were collected in black plastic film cans by

Table 1. The single aliquot regeneration (SAR) protocol that was used for the analyses. The given doses were in the range 1-1.2 Gy (run $2=$ run 6), 2-2.4 Gy (run 3), 3-3.7 Gy (run 4) and 0 Gy (run 5 = recuperation). The test dose was $\sim 1.5 \mathrm{~Gy}$. The infrared to blue ratio of each aliquot was measured as a final step after run 6 .

\begin{tabular}{cl}
\hline step & Procedure \\
\hline 1 & Pre-heat $200^{\circ} \mathrm{C}$ \\
2 & OSL Blue LEDs $125^{\circ} \mathrm{C} 40 \mathrm{~s}$ \\
3 & Test dose \\
4 & TL $180^{\circ} \mathrm{C}$ \\
5 & OSL Blue LEDs $125^{\circ} \mathrm{C} 40 \mathrm{~s}$ \\
6 & Illumination blue LEDs $280^{\circ} \mathrm{C} 40 \mathrm{~s}$ \\
7 & Dose, return to step 1 \\
\hline
\end{tabular}

scooping up the topmost sediments of the river beds (051332-35) and the ground surface (051337) and digging into a sidebar (051331). The cans were stored in opaque plastic bags until opened under subdued orange light in the laboratory at the Nordic Laboratory for Luminescence Dating, Risø, Denmark. The samples were wetsieved to get grain sizes $>63 \mu \mathrm{m}$ (cf. Table 2) and sedimentation analyses was used to exclude grains $<10 \mu \mathrm{m}$. The sieved sub-samples were treated with $10 \% \mathrm{HCl}, 10 \%$ $\mathrm{H}_{2} \mathrm{O}_{2}$ and concentrated HF (30-60 minutes, depending on grain size) according to standard procedure. Eight-mm aliquots were analysed using the SAR protocol (Table 1; Murray and Wintle, 2000; 2003) on automated Risø TL/OSL readers. The quartz grains were stimulated at $125^{\circ} \mathrm{C}$ with blue light $(470 \pm 20 \mathrm{~nm})$ and detected in the 290-370 nm (Hoya U340) wavelength band.

\section{SITE DESCRIPTIONS}

The studied sites are situated on Jameson Land, East Greenland (Fig. 1). Jameson Land consists mainly of Jurassic sedimentary bedrock (sandstone, shale) that is partly covered by glacial deposits of various ages. These deposits also contain igneous and metamorphous bedrock clasts (e.g. gneiss, quartzite), brought by ice sheets and glaciers from surrounding areas. 
The Fynselv River (Fig. 2a) drains part of central Jameson Land, including several perennial snowfields in the Mt. JP Koch Fjeld area. In its upper reaches it flows in a deep canyon. Here the river mainly has a stony gravelly bed, but sandy deposits are found in backwaters and behind boulders that have fallen from the canyon walls. At the site the river is $\sim 7 \mathrm{~m}$ wide and 0.1-0.6 m deep. Sample 051332 was taken from a rippled leeside deposit at $30 \mathrm{~cm}$ water depth.

The Gåseelv River (Fig. 2b) runs in one of the major valleys on eastern Jameson Land. Its bed is mainly stonygravelly but some sand bars occur. It has a braided flow pattern, with up to $4 \mathrm{~m}$ wide and $0.5 \mathrm{~m}$ deep channels. Sample 051333 was taken from sandy ripples covering a gravelly longitudinal bar (15 cm water depth). Around the time of sampling (August), the Gåseelv River was characterised by a significant amount of suspended material and the river bed was not visible if water was deeper than $15-20 \mathrm{~cm}$. Several perennial snow patches are found in the catchment, the closest within a few kilometres from the site.

The Hesteelv River (Fig. 2c) drains part of southeastern Jameson Land and due to diversion by the large Flakkerhuk moraine it flows parallel to the coast for ca $4 \mathrm{~km}$ before entering the sea. Its catchment includes several perennial snowfields. The river is braided, ca $50 \mathrm{~m}$ wide and on average $0.5 \mathrm{~m}$ deep at the site. Sample 051334 was taken from sandy ripples on a longitudinal bar, at 10 cm water depth.

The Umingmakelv River (informal name; Fig. 2d) cuts into the base of Mt. Umingmakbjerg and partly runs in a $<50 \mathrm{~m}$ deep canyon. It drains two valleys that harbour a number of perennial snowfields, the closest of which are $\sim 2 \mathrm{~km}$ upstream. At the site the river is $5-8 \mathrm{~m}$ wide, ca 0.1-0.2 m deep and has a sandy-gravelly bottom. Boulders also occur, derived from adjacent glaciofluvial sediments and till. The water was relatively turbid, but the river bed was visible at all depths. Sample 051335 was taken at $15 \mathrm{~cm}$ water depth, from the surface of a small sandy sidebar with ripples. Sample 051331 is from an exposed sidebar most likely deposited during spring flood at the mouth of a small contributory stream.

The Gåseelv and Umingmakelv rivers showed a clear diurnal pattern related to snow melt with increased water levels and flows during the afternoon compared to the morning. The behaviour of the Hesteelv and Fynselv rivers could not be observed in the same way due to limited time spent there.

In the innermost Ugleelv Valley, the Ugleelv River has cut into $100 \mathrm{~m}$ of Quaternary deposits. Sample 051337 was taken from a modern thin deposit of partly windblown, partly sheet wash deposit on a northwestfacing surface of the upper part of the valley side.

\section{RESULTS}

\section{Luminescence characteristics}

Since the samples are very young the luminescence signals are very weak, and for several aliquots there is no discernible signal at all. However, decay curves after regeneration doses show clear signals for the majority of aliquots (Fig. 3) and suggest that the lack of signal is due to the young age and not an inherent characteristic of the material. Growth curves are generally linear or exponential (inset of Fig. 3).

Most samples have some or substantial infrared-toblue signal ratios, which indicate that feldspar is still present in the samples. However, equivalent doses are largely independent of the size of the IR signal (Fig. 4) and IR contamination does therefore not seem to be a significant problem. The equivalent dose is also independent of preheat temperatures up to $\sim 260^{\circ} \mathrm{C}$, where thermal transfer sets in (Fig. 5). Thermal transfer may contribute $\sim 1-1.5$ Gy at $260^{\circ} \mathrm{C}$ preheat and up to 9 Gy at $300^{\circ} \mathrm{C}$ preheat.

Recycling is generally less than unity, on average $0.81 \pm 0.36$, while recuperation varies widely around an average of $-80 \%$ of the natural (a factor of -80 to 210 ). Only a few dose recovery measurements could be made due to the small amount of material available (due to small initial sample volume, partly containing mainly large grain sizes) but they suggest an underestimation $(0.87 \pm 0.11, n=12)$ of the given dose. Dose recovery measurements with high doses (ca $30 \mathrm{~Gy}$ ) perform better (ca1.05, n=2).

\section{Equivalent doses}

With the exception of the finest grain-size fraction,

Table 2. Sample information and equivalent doses with standard errors. Geographic positions and altitudes were measured with a Gramin Vista C GPS

\begin{tabular}{|c|c|c|c|}
\hline$\overline{\text { Sample }}$ & $\begin{array}{c}\text { Grain size } \\
(\mu \mathrm{m})\end{array}$ & $\begin{array}{l}\text { Dose } \\
\text { (Gy) }\end{array}$ & $n$ \\
\hline 051332 & $63-106$ & -0.08 & 1 \\
\hline Fynselv R. & $106-180$ & $0.08 \pm 0.05$ & 5 \\
\hline N7035.511 & $180-250$ & $-0.05 \pm 0.09$ & 3 \\
\hline W23015.977 & $250-300$ & $0.02 \pm 0.03$ & 3 \\
\hline 175 m a.s.l. & $300-500$ & $0.17 \pm 0.07$ & 3 \\
\hline 051333 & $106-180$ & $0.13 \pm 0.05$ & 3 \\
\hline Gåseelv R. & $180-250$ & $0.34 \pm 0.11$ & 3 \\
\hline $\mathrm{N} 70^{\circ} 46.880$ & $250-300$ & $0.03 \pm 0.02$ & 3 \\
\hline W22 46.915 & $300-500$ & $0.06 \pm 0.04$ & 3 \\
\hline \multicolumn{4}{|l|}{53 m a.s.l. } \\
\hline 051334 & $106-180$ & $0.29 \pm 0.32$ & 3 \\
\hline Hesteelv R. & $180-250$ & $0.09 \pm 0.06$ & 6 \\
\hline $\mathrm{N} 70^{\circ} 27.007$ & $250-300$ & $0.00 \pm 0.14$ & 3 \\
\hline$W^{2} 3^{\circ} 06.768$ & $300-500$ & $0.03 \pm 0.03$ & 3 \\
\hline \multicolumn{4}{|l|}{$5 \mathrm{~m}$ a.s.l. } \\
\hline 051335 & $10-63$ & $1.14 \pm 0.39$ & 6 \\
\hline Umingmakelv $\mathbf{R}$. & $63-106$ & $0.13 \pm 0.05$ & 6 \\
\hline N71 08.514 & $106-180$ & $0.22 \pm 0.06$ & 6 \\
\hline W2246.846 & $180-250$ & $0.13 \pm 0.04$ & 6 \\
\hline \multirow[t]{2}{*}{255 m a.s.I. } & $250-300$ & $0.02 \pm 0.03$ & 5 \\
\hline & $300-500$ & $-0.07 \pm 0.05$ & 6 \\
\hline \multicolumn{4}{|l|}{051331} \\
\hline \multicolumn{4}{|l|}{ Umingmakelv $\mathbf{R}$. } \\
\hline N71 08.502 & $180-250$ & $0.96 \pm 0.19$ & 9 \\
\hline \multicolumn{4}{|l|}{ W22 $2^{\circ} 46.680$} \\
\hline \multicolumn{4}{|l|}{256 m a.s.l. } \\
\hline \multicolumn{4}{|l|}{051337} \\
\hline \multicolumn{4}{|l|}{ Ugleelv R. valley } \\
\hline N70 55.025 & $180-250$ & $0.00 \pm 0.07$ & 6 \\
\hline W230․ 070 & & & \\
\hline $466 \mathrm{~m}$ a.s.l. & & & \\
\hline
\end{tabular}




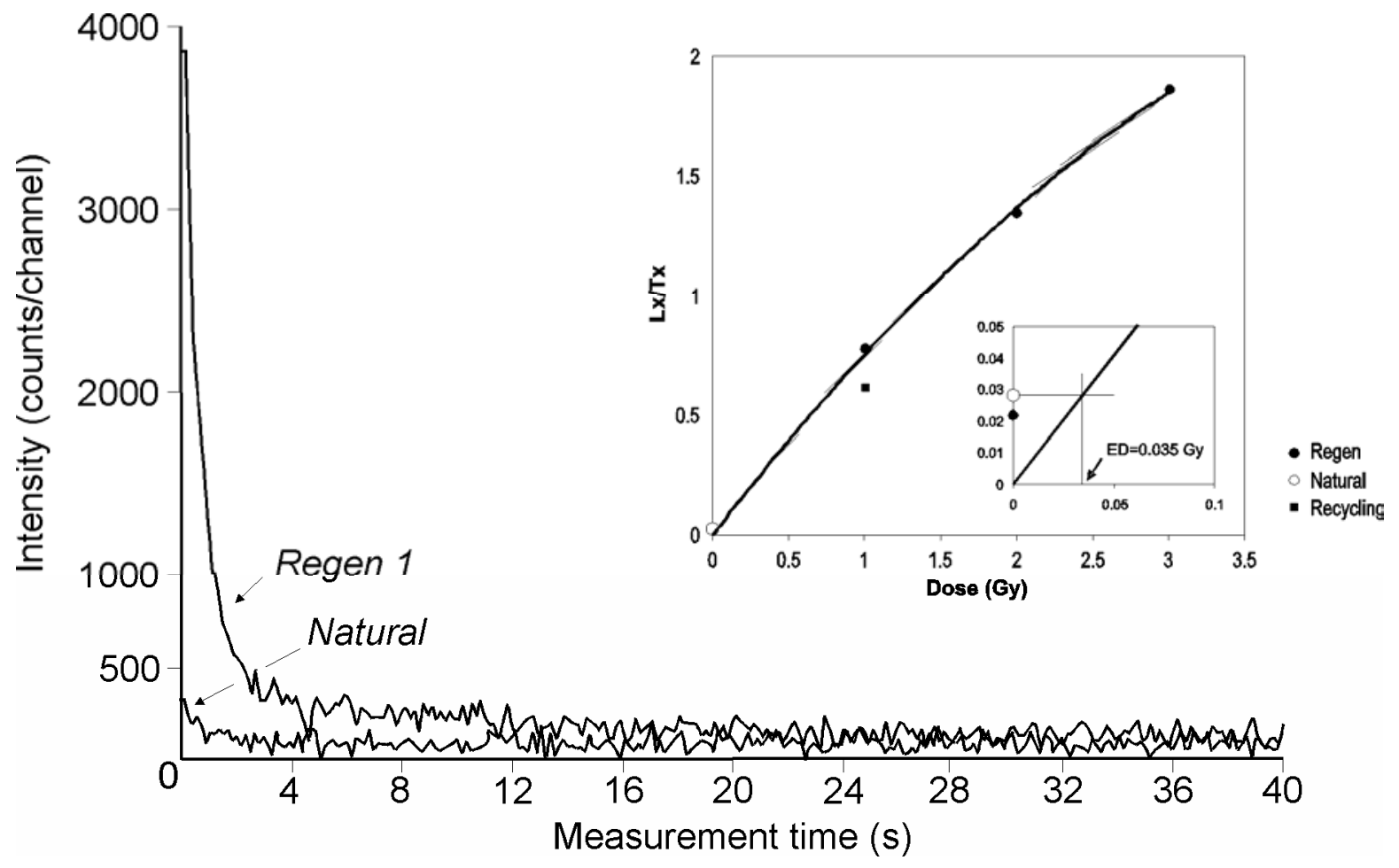

Fig. 3. Example of the OSL decay curve from sample 051335 (250-300 $\mu \mathrm{m})$. The growth curve for the same aliquot is shown in the inset.

the equivalent doses of the modern river bed sediments are generally small ( $\sim 0.1$ Gy), although not zero (Table 2; Fig. 6). The silt grains $(10-63 \mu \mathrm{m})$ stand out as having larger equivalent doses $(1.1 \mathrm{~Gy})$ than the coarser material. The samples from the four different rivers are relatively similar with small variations (Fig. 6). The Hesteelv and Umingmakelv river samples show a general decrease in equivalent dose with increasing grain size; the other two have no clear trends.

The equivalent dose of the spring flood deposit (051331) is ca $1 \mathrm{~Gy}$, which corresponds to ca 500 years (dose rate $1.90 \pm 0.07 \mathrm{~Gy} / \mathrm{ka}$; measured with gamma spectrometry) and is about 10 times higher than the doses of the river bed samples. In comparison, the subaerial deposit (051337) is completely zeroed ( $E D=0.00 \pm 0.07 \mathrm{~Gy})$.

\section{DISCUSSION}

\section{Measurements and doses}

The samples have rather poor luminescence characteristics and with standard discrimination limits (i.e. discard aliquots with IR/blue signal ratio $>10 \%$, recuperation $>5 \%$ and recycling $<0.9$ or $>1.1$ ), very few of the measured aliquots would remain. Those remaining give, however, similar results as the rest (river beds $0.2 \mathrm{~Gy}, \mathrm{n}=4$; spring flood deposit $1 \mathrm{~Gy}, \mathrm{n}=1$ ) but the low number of aliquots prevents any statistical comparison. The aliquots measured with high doses (30 Gy dose recovery) perform better and suggest that the poor behaviour of these young samples is likely mainly due to low signal levels. Significant thermal transfer, which has been a problem in some glaciofluvial environments (Rhodes and Bailey,

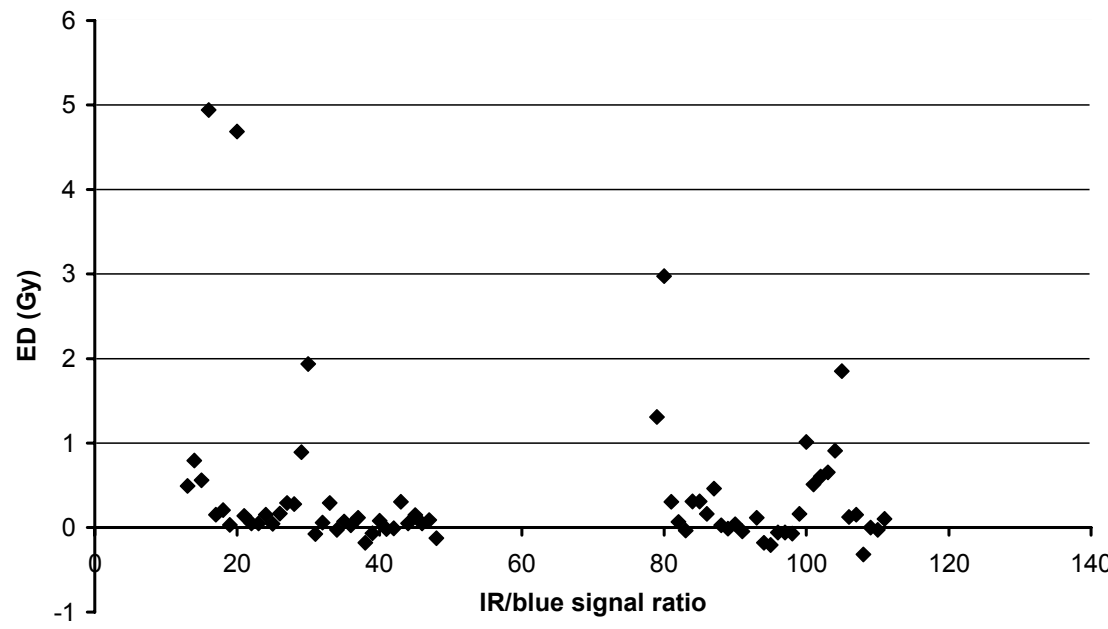

Fig. 4. A plot of equivalent dose versus infrared/blue signal ratio indicates that the equivalent doses are largely independent of the size of the IR signal. Signals were calculated in the same way for all samples; the integrated signal of channels 26-50 (divided by five; background) was subtracted from channels 1-5 (peak). Absolute signal magnitudes for the aliquots presented here varied from -54 to 8030 counts per channel (blue) and from -30 to $400 \mathrm{c} \mathrm{ch}^{-1}$ (IR). 


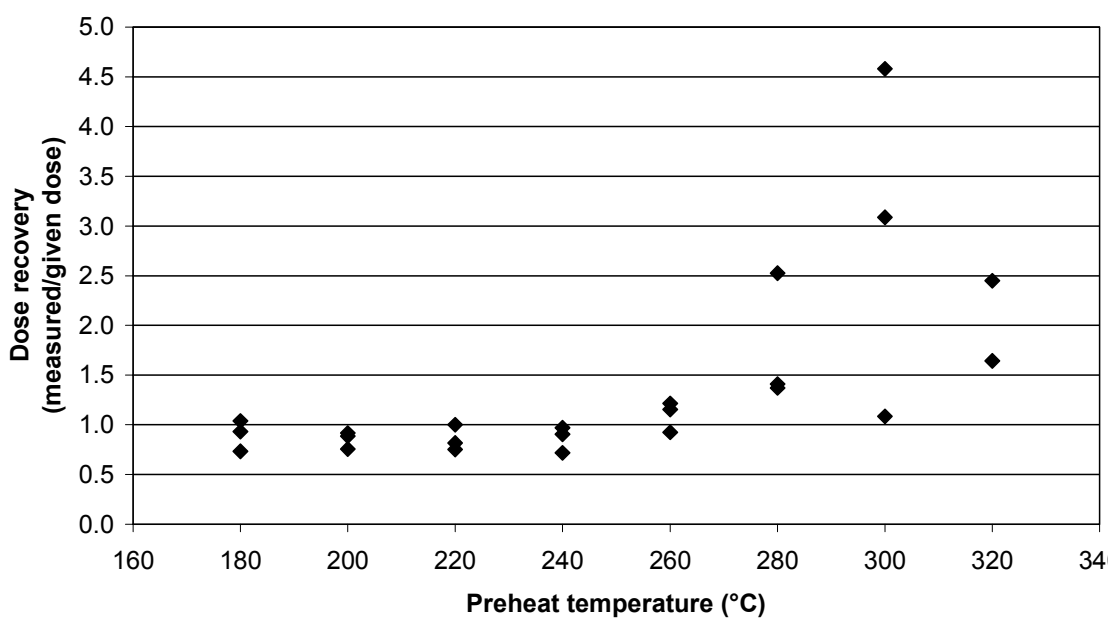

Fig. 5. Preheat plateau measurement (dose recovery) of sample 051331. The equivalent dose is independent of preheat temperatures up to $260^{\circ} \mathrm{C}$.
1997; Rhodes 2000), is noticeable only if preheat temperatures $\geq 260^{\circ} \mathrm{C}$ are used. However, the large recuperation for some aliquots suggest that thermal transfer may be present also at lower temperatures in some cases.

Due to incomplete bleaching, the present-day sediments in the rivers have apparent ages of 50-500 years. This is lower than the few thousand years of incomplete bleaching estimated for Holocene sediments by Hansen $e t$ al. (1999) but comparable to the lower age (dose) range in modern fluvial and glaciofluvial settings in other areas (Wallinga, 2002; Jain et al., 2004). The relatively small spread of equivalent doses (0-1.1 Gy) does not reflect the variation in channel width, depth, discharge, sediment load and likely transport distance for the different rivers. Systematic sampling of both bar and channel facies along downstream transects would be needed to elucidate the effects of individual factors, but as a whole the results indicate that sediment in bedload transport in these rivers is fairly well bleached.

There is a striking difference in equivalent dose between the silt- and the sand-sized grains. The sand grains have significantly lower doses and for the Hesteelv and Umingmakelv rivers there is also a slight decrease in ED with increasing grain size within the sand fraction (Fig. 6). The same phenomenon has been observed by Olley et al. (1998), Colls et al. (2001) and Truelsen and Wallinga (2003) in fluvial environments. A complete explanation has not been presented so far, but flocculation of and mud-coating on fine grains and grain-size dependent transport paths have been suggested as possi-

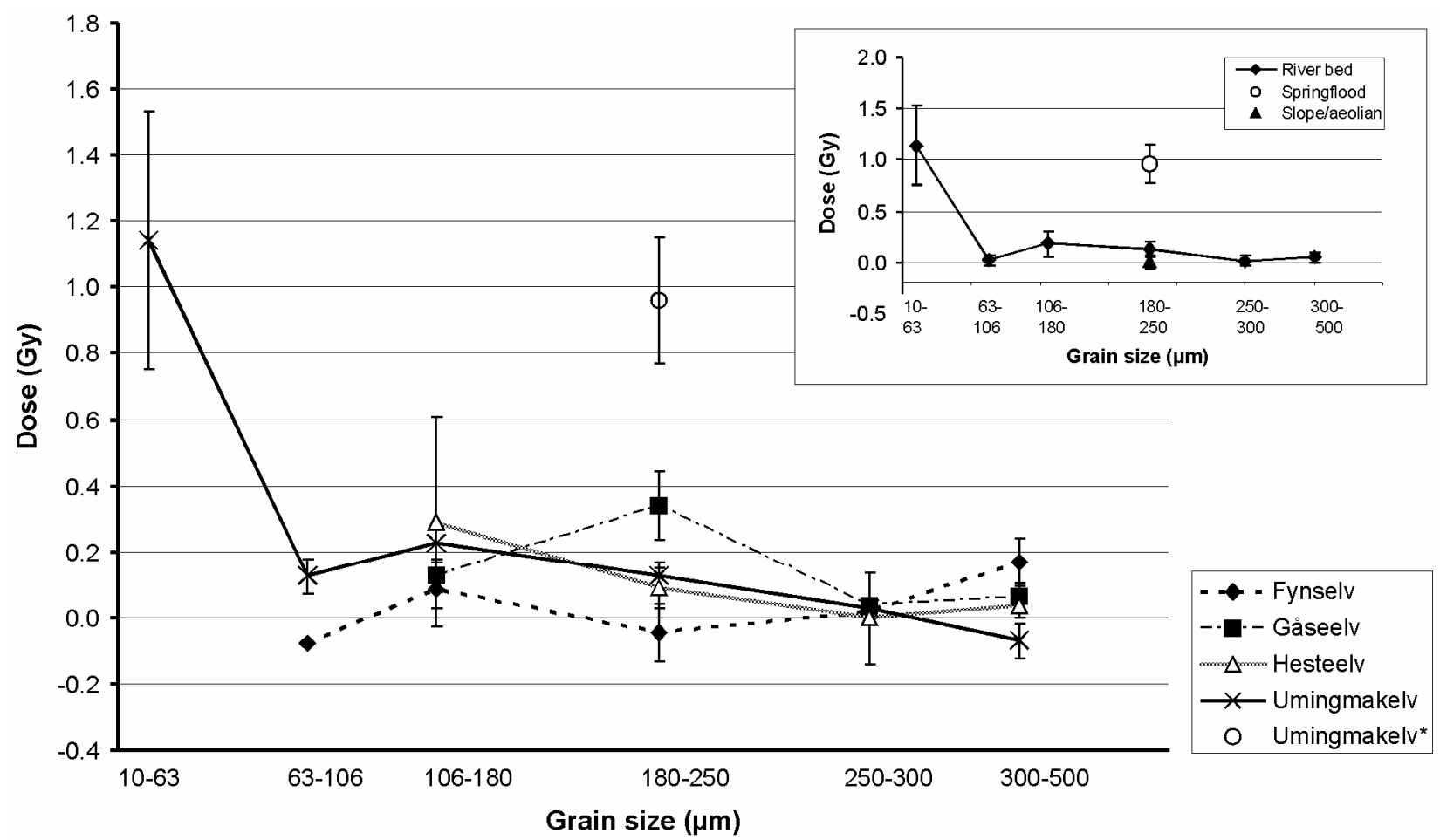

Fig. 6. Dose dependency of grain size for the modern rivers and the spring flood deposit (Umingmakelv*). The inset is summary diagram showing the mean of each grain size from all river bed samples compared to the spring flood sample and the reference subaerial (slope/aeolian) deposit. Bars denote standard errors. 
ble contributing factors (Fuchs et al., 2005; Truelsen and Wallinga, 2003). The observations in this study suggest that relatively coarse grain sizes should be preferred for OSL-dating of fluvial or glaciofluvial sediments (cf. Wallinga, 2002; Truelsen and Wallinga, 2003). This is in contrast to Rhodes and Bailey (1997) who, based on measurements of modern glaciofluvial sediments in western Greenland, recommend sampling fine grain sizes for optical dating.

\section{Comparison to ancient depositional settings}

The Pleistocene glaciofluvial and glaciolacustrine sediments in the area were deposited mostly as deltas and terraces in valleys, which at times contained ice-dammed lakes. The sediment input came not just from the damming glaciers but also from surrounding areas, as indicated by different palaeoflow directions. The sediments consist of horizontally laminated, cross- and ripplelaminated and massive sands that suggest deposition in channels and on bars as well as in deeper, calmer water. The sedimentology and geomorphology of the valleys are described in more detail by Lillieskiöld and Salvigsen (1991), Adrielsson and Alexanderson (2005) and Alexanderson (unpublished data).

The modern analogues were taken from ripplelaminated sandy surfaces on longitudinal bars and sidebars in (for the area) small and medium-sized rivers. The drainage (sediment source) area is largely the same as during glacial times, apart from the considerable glacier/ice-sheet input. However, since the present-day sediments are derived from erosion of the glacial deposits it is unlikely that there are any major geological (petrological) differences between them.

The sampled rivers were, with the exception of some pools, fairly shallow ( $<1 \mathrm{~m}$ deep). During spring flood river levels were at least $0.5-1 \mathrm{~m}$ higher, as indicated by geomorphology and vegetation. However, even spring flood levels (water depths), discharge and turbidity are likely to be lower than those during deglaciation, when nearby glaciers provided large amounts of melt water. From a hydrological perspective, the present-day rivers should be considered to represent minimum-to-normal glacial discharges; perhaps more similar to an area with dead-ice disintegration than active glacier advance or retreat. The spring flood sediments were, on the other hand, deposited during a high discharge event and are more analogous in nature, although not necessarily in magnitude, to deglacial conditions.

The samples were taken during summer (August) when the rivers have relatively low water level and sunlight is most long-lasting ( $\leq 24$ hours/day) and intensive. This suggests optimal conditions for bleaching in this type of environment and the samples should ideally give zero dose. The residual dose was, however, not zero but nonetheless very small ( $\sim .1 \mathrm{~Gy}$; Table 2$)$. From an incomplete bleaching point of view, it is likely that this is 'as good as it gets' for glaciofluvial sediments in the area.

During the Late Weichselian, when a large amount of the glaciofluvial and glaciolacustrine sediments in the valleys of eastern Jameson Land was deposited, the climate was drier and colder than present (Johnsen et al., 1992; Funder et al., 1998). It seems to have been more dust in the air (Johnsen et al., 1992) but the effect of this on e.g. cloudiness (and sunlight availability) is unknown. The insolation at that time was the same or larger than today (Berger, 1978) and after the Last Glacial Maximum, peaks in insolation coincided in time with the snow melt season (Berger, 1979). Today, snow melt takes place during insolation minima (Berger, 1979).

Thus, the modern samples consist of the same lithofacies and of the same type of material as the Pleistocene glaciofluvial sediments and they were deposited by similar or smaller discharges. The modern rivers have input only from perennial snow patches and not active glaciers, which is an important difference that cannot be helped, unfortunately. It is not possible to compare bleaching conditions (sunlight intensity, duration, etc.) due to limited knowledge of past circumstances.

\section{Implications for dating Pleistocene glaciofluvial sedi- ments}

The Pleistocene glaciofluvial and glaciolacustrine sediments in the area have equivalent doses of $20 \mathrm{~Gy}$ to $>400$ Gy (Adrielsson and Alexanderson, 2005; Alexanderson, unpublished data). Incomplete bleaching of the order of $1 \mathrm{~Gy}$, as indicated by the spring-flood deposit, is not a significant source of error ( $>5 \%$ of ED) even for the youngest samples.

These values are valid for sediments that have been transported some distance $(\sim 1-2 \mathrm{~km})$ in the river. Grains deposited very close to an ice margin, for example at the glacier that once dammed the valley, are probably less well bleached and may therefore have higher residual doses. Sediments that derive from surrounding areas rather than from the glacier (identified through palaeoflow directions) are more likely to have longer transport distances and greater chances of bleaching and should thus be preferably selected for dating.

\section{CONCLUSIONS}

- Recent sandy river bed sediments in distal glaciofluvial environments have very small residual doses (ca $0.1 \mathrm{~Gy}$ ). This is considered to be the best possible degree of bleaching for glaciofluvial sediments in the area and may be representative of deposition during minimum-to-normal melt water discharges during glacial times.

- Silt-sized grains have significantly higher equivalent doses (ca $1.1 \mathrm{~Gy}$ ) than sand grains ( ca $0.1 \mathrm{~Gy}$ ). This suggests that coarse size fractions are better bleached and more suitable than fine grains for OSL dating of glaciofluvial/fluvial sediments.

- Sediments deposited during the spring flood have a residual dose of ca 1 Gy (corresponding to $500 \mathrm{yrs}$ ), which is assumed to be more similar to deglaciation conditions. Incomplete bleaching of this amount would be a significant source of error only for samples aged $10 \mathrm{ka}$ and less ( $<20 \mathrm{~Gy})$ from this area.

- A subaerial reference deposit is completely zeroed.

- Most samples have rather poor luminescence characteristics, likely due to the low signal levels, and suffer from some IR contamination, which does not seem to 
affect the value of the equivalent dose. Thermal transfer may contribute with $\geq 1.5$ Gy if preheat temperatures at or above $260^{\circ} \mathrm{C}$ are used.

\section{ACKNOWLEDGEMENTS}

NordForsk financed the author's stay at the Nordic Laboratory for Luminescence Dating, and fieldwork on Jameson Land was financed by the Swedish Society for Anthropology and Geography, the Helge Ax:son Johnson Foundation, the Royal Physiographic Society, Japetus Stenstrup's Foundation and the Royal Academy of Sciences. Thanks to Lena Håkansson for good teamwork in the field and to all colleagues at NLL/NUK (Risø National Laboratory) and INK (Stockholm University) for helpful discussions.

\section{REFERENCES}

Adrielsson L and Alexanderson H, 2005. Interactions between the Greenland Ice Sheet and the Liverpool Land coastal ice cap during the last two glaciation cycles. Journal of Quaternary Science 20(3): 269-283.

Alexanderson H and Håkansson L, 2006. The last glacial cycle on Jameson Land, East Greenland: local glaciation, ice-free conditions and perhaps an ice sheet. Abstract volume, $36^{\text {th }}$ International Arctic Workshop, Boulder, Co. USA, March 2006. Also available online at http://instaar.colorado.edu/AW/ abstract detail.php?abstract $\mathrm{id}=26$

Alexanderson $\bar{H}$ and Murray $\overline{A S}$, in press. Was southern Sweden ice free at 19-25 ka, or were the post LGM glacifluvial sediments incompletely bleached? Quaternary Geochronology.

Berger AL, 1978. Long-term variations of caloric insolation resulting from the Earth's orbital elements. Quaternary Research 9: 139167.

Berger AL, 1979. Insolation signatures of Quaternary climate changes. Il Nuovo Cimento 2C, 1: 63-87.

Bøe AG, Dahl SO, Murray A, Lie Ø and Nesje A, in press. Optically stimulated luminescence characteristics and dating of Late Weichselian ice-front glaciofluvial deposits in the Rondane area, eastcentral southern Norway. Quaternary Science Reviews - Quaternary Geochronology.

Colls AE, Stokes S, Blum MD and Straffin E, 2001. Age limits on the Late Quaternary evolution of the upper Loire River. Quaternary Science Reviews 20: 743-750.

Duller GAT, 1994. Luminescence dating of poorly bleached sediments from Scotland. Quaternary Geochronology (Quaternary Science Reviews) 13: 521-524.

Fuchs M, Straub J and Zöller L, 2005. Residual luminescence signals of recent river flood sediments: A comparison between quartz and feldspar of fine- and coarse-grain sediments. Ancient TL 23: 25-30.

Funder S, Hjort C, Landvik JY, Nam S-I, Reeh N and Stein R, 1998. History of a stable ice margin - East Greenland during the Middle and Upper Pleistocene. Quaternary Science Reviews 17: 77-123.

Gemmell AMD, 1988. Zeroing of the TL signal in sediment undergoing fluvioglacial transport. An example from Austerdalen, western Norway. Quaternary Science Reviews 7: 339-345.

Gemmell AMD, 1994. Environmental controls on the TL age of modern (zero-age) proglacial outwash sediments. Quaternary Geochronology (Quaternary Science Reviews) 13: 485-489.

Gemmell AMD, 1997. Fluctuations in the thermoluminescence signal of suspended sediment in an alpine glacial meltwater stream. Quaternary Science Reviews (Quaternary Geochronology) 16: 281-290.

Gemmell AMD, 1999. IRSL from fine-grained glacifluvial sediment. Quaternary Geochronology 18: 207-215.

Godfrey-Smith DI, Huntley DJ and Chen W-H, 1988. Optical dating studies of quartz and feldspar sediment extracts. Quaternary Science Reviews 7: 373-380.

Hansen L, Funder S, Murray AS and Mejdahl V, 1999. Luminescence dating of the last Weichselian Glacier advance in East Greenland. Quaternary Geochronology 18: 179-190.
Hoffower H, 2002. Application of optically-stimulated luminescence dating to modern and Pleistocene glacio-fluvial deposits. The Geological Society of America (GSA) meeting, Denver, Co. USA, October 2002. Online at http://gsa.confex.com/gsa/2002AM/ finalprogram/abstract_45584.htm

Håkansson L, Alexanderson H, Aldahan A, Briner J, Hjort C and Possnert G, 2006. Using cosmogenic isotopes to reconcile two contrasting hypotheses for ice extent in East Greenland during the last glaciation. Abstract volume, $36^{\text {th }}$ International Arctic Workshop, Boulder, Co. USA, March 2006. Also online at http://instaar.colorado.edu/AW/

abstract_detail.php?abstract_id=55.

Jain M, Murray AS and Bøtter-Jensen L, 2004. Optically stimulated luminescence dating: How significant is incomplete light exposure in fluvial environments? Quaternaire 15: 143-157.

Johnsen SJ, Clausen HB, Dansgaard W, Gundestrup NS, Hansson M, Jonsson P, Steffensen JP and Sveinbjørnsdottir AE, 1992. A "deep" ice core from East Greenland. Meddelelser om Grønland, Geoscience 29: 3-22.

Kjær KH, Lagerlund E, Adrielsson L, Thomas PJ, Murray A and Sandgren P, 2006. The first independent chronology for Middle and Late Weichselian sediments from southern Sweden and the island of Bornholm. GFF 128: 209-220.

Lilliesköld M and Salvigsen O, 1991. Glacial features and stratigraphy on eastern Jameson Land. LUNDQUA Report 33: 111-116.

Mejdahl V and Funder S, 1994. Luminescence dating of Late Quaternary sediments from East Greenland. Boreas 23: 525-535.

Murray AS and Wintle AG, 2000. Luminescence dating of quartz using an improved single aliquot regenerative-dose protocol. Radiation Measurements 32: 57-73.

Murray AS and Wintle AG, 2003. The single aliquot regenerative dose protocol: potential for improvements in reliability. Radiation Measurements 37: 377-381.

Mäkinen K, 2005. Dating the Weichselian deposits of southwestern Finnish Lapland. In: Ojala A.E.K., ed., Quaternary studies in the northern and Arctic regions of Finland. Geological Survey of Finland, Special Paper 40: 67-78.

Olley J, Caitcheon G and Murray A, 1998. The distribution of apparent dose as determined by optically stimulated luminescence in small aliquots of fluvial quartz: implications for dating young sediments. Quaternary Geochronology 17: 1033-1040.

Owen LA, Kamp U, Spencer JQ and Haserodt K, 2002. Timing and style of Late Quaternary glaciatioon in the eastern Hindu Kush, Chitral, northern Pakistan: a review and revision of the glacial chronology based on new optically stimulated luminescence dating. Quaternary International 97-98: 41-55.

Preusser F, Andersen BG, Denton GH and Schlüchter C, 2005. Luminescence chronology of Late Pleistocene glacial deposits in North Westland, New Zealand. Quaternary Science Reviews 24: 22072227.

Rhodes EJ, 2000. Observations of thermal transfer OSL signals in glacigenic quartz. Radiation Measurements 32: 595-602.

Rhodes EJ and Bailey RM, 1997. The effect of thermal transfer on the zeroing of the luminescence of quartz from recent glaciofluvial sediments. Quaternary Science Reviews (Quaternary Geochronology) 16: 291-298.

Rhodes EJ and Pownall L, 1994. Zeroing of the OSL signal in quartz from young glaciofluvial sediments. Radiation Measurements 23(2/3): 581-585.

Richards BWM, 2000. Luminescence dating of Quaternary sediments in the Himalaya and High Asia: a practical guide to its use and limitations for constraining the timing of glaciation. Quaternary International 65/66: 49-61.

Richards BW, Owen LA and Rhodes EJ, 2000. Timing of Late Quaternary glaciations in the Himalayas of northern Pakistan. Journal of Quaternary Science 15(3): 283-297.

Spencer JQ and Owen LA, 2004. Optically stimulated luminescence dating of Late Quaternary glaciogenic sediments in the upper Hunza valley: validating the timing of glaciation and assessing dating methods. Quaternary Science Reviews 23: 175-191.

Stokes S, Bray HE and Blum MD, 2001. Optical resetting in large drainage basins: tests of zeroing assumptions using single-aliquot procedures. Quaternary Science Reviews 20: 879-885.

Svendsen JI, Alexanderson H, Astakhov VI, Demidov I, Dowdeswell JA, Funder S, Gataullin V, Henriksen M, Hjort C, HoumarkNielsen M, Hubberten HW, Ingólfsson Ó, Jakobsson M, Kjær KH, Larsen E, Lokrantz H, Lunkka JP, Lyså A, Mangerud J, Ma- 
tioushkov A, Murray A, Möller P, Niessen F, Nikolskaya O, Polyak L, Saarnisto M, Siegert C, Siegert MJ, Spielhagen RF and Stein R, 2004. Late Quaternary ice sheet history of northern Eurasia. Ouaternary Science Reviews 23(11-13): 1229-1271.

Thackray GD, Shulmeister J, Rieser U, Marra M and Woodward C, 2005. New OSL glacial chronology from the Rakaia Valley, New Zealand. Geological Society of America, Salt Lake City, USA, October 2005. Abstracts with Programs, vol. 37(7): 40. Also online at http://gsa.confex.com/gsa/2005AM/finalprogram/ abstract 93085.htm

Truelsen JL and Wallinga J, 2003. Zeroing of the OSL signal as a function of grain size: investigating bleaching and thermal transfer for a young fluvial sample. Geochronometria 22: 1-8.

Wallinga J, 2002. Optically stimulated luminescence dating of fluvial deposits: a review. Boreas 31: 303-322. 